\title{
Effect of storage conditions on SARS-CoV-2 RNA quantification in wastewater solids
}

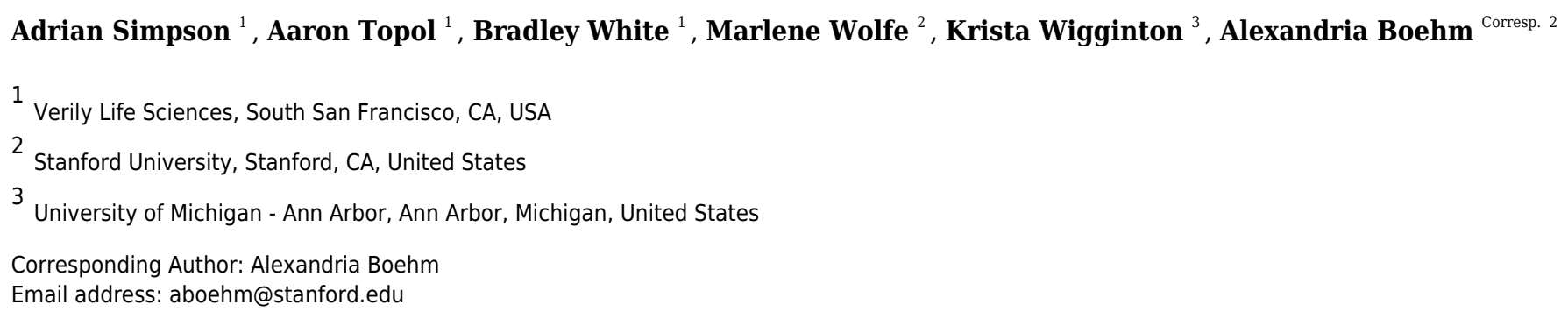

SARS-CoV-2 RNA in wastewater settled solids is associated with COVID-19 incidence in sewersheds and therefore, there is a strong interest in using these measurements to augment traditional disease surveillance methods. A wastewater surveillance program should provide rapid turn around for sample measurements (ideally within 24 hours), but storage of samples is necessary for a variety of reasons including biobanking. Here we investigate how storage of wastewater solids at $4{ }^{\circ} \mathrm{C},-20^{\circ} \mathrm{C}$, and $-80^{\circ} \mathrm{C}$ affects measured concentrations of SARS-CoV-2 RNA. We find that short term (7 or $8 \mathrm{~d}$ ) storage of raw solids at $4^{\circ} \mathrm{C}$ has little effect on measured concentrations of SARS-CoV-2 RNA, whereas longer term storage at $4^{\circ} \mathrm{C}$ (35-122 d) or freezing reduces measurements by $60 \%$, on average. We show that normalizing SARS-CoV-2 RNA concentrations by concentrations of pepper mild mottle virus (PMMoV) RNA, an endogenous wastewater virus, can correct for changes during storage as storage can have a similar effect on PMMoV RNA as on SARS-CoV-2 RNA. The reductions in SARS-CoV-2 RNA in solids during freeze thaws is less than those reported for the same target in liquid influent by several authors. 


\title{
1 Effect of storage conditions on SARS-CoV-2 RNA
}

2 quantification in wastewater solids

3

4

Adrian Simpson $^{1}$, Aaron Topol ${ }^{1}$, Bradley White ${ }^{1}$, Marlene K. Wolfe ${ }^{2}$, Krista Wigginton ${ }^{3}$, Alexandria B. Boehm²

${ }^{1}$ Verily Life Sciences, South San Francisco, 94080, California, United States

${ }^{2}$ Civil and Environmental Engineering, Stanford University, Stanford, California, United States

${ }^{3}$ Civil and Environmental Engineering, University of Michigan, Ann Arbor, Michigan, United States

Corresponding Author:Alexandria B. Boehm 473 Via Ortega, Stanford, CA, 94305, USA

Email address: aboehm@stanford.edu

\begin{abstract}
SARS-CoV-2 RNA concentrations in wastewater settled solids is associated with COVID-19 incidence in sewersheds and therefore, there is a strong interest in using these measurements to augment traditional disease surveillance methods. A wastewater surveillance program should provide rapid turn around for sample measurements (ideally within 24 hours), but storage of samples is necessary for a variety of reasons including biobanking. Here we investigate how storage of wastewater solids at $4^{\circ} \mathrm{C},-20^{\circ} \mathrm{C}$, and $-80^{\circ} \mathrm{C}$ affects measured concentrations of SARS-CoV-2 RNA. We find that short term (7 or $8 \mathrm{~d}$ ) storage of raw solids at $4^{\circ} \mathrm{C}$ has little effect on measured concentrations of SARS-CoV-2 RNA, whereas longer term storage at $4^{\circ} \mathrm{C}$ (35-122 d) or freezing reduces measurements by $60 \%$, on average. We show that normalizing SARS-CoV-2 RNA concentrations by concentrations of pepper mild mottle virus (PMMoV) RNA, an endogenous wastewater virus, can correct for changes during storage as storage can have a similar effect on PMMoV RNA as on SARS-CoV-2 RNA. The reductions in SARS-CoV-2 RNA in solids during freeze thaws is less than those reported for the same target in liquid influent by several authors.
\end{abstract}

\section{Introduction}

SARS-CoV-2 RNA in settled solids from wastewater treatment plants correlates to COVID-19 incidence in the sewershed population [1-5]. As a result, local and federal governmental agencies are establishing wastewater-based epidemiology methods to help inform pandemic response [6]. SARS-CoV-2 RNA concentrations are measured in the wastewater and information about the incidence of COVID-19 can be inferred from the measurement concentrations [1-5]. 
42 Wastewater consists of liquid and solid components. While many wastewater surveillance 43 efforts have focused on measuring SARS-CoV-2 RNA in the liquid component of wastewater $44[7,8]$, the solids have $10^{3}$ to $10^{4}$ higher concentrations of SARS-CoV-2 RNA on a per mass basis $45[2,9]$. Settled solids are readily collected from the primary clarifier where they settle as part of 46 the wastewater treatment process (often referred to as sludge), or they can be settled from wastewater influent using standard method SM2540 F [10] if a wastewater treatment plant does not have a primary clarifier unit process.

In order for wastewater data on SARS-CoV-2 RNA concentrations to be useful for wastewater based epidemiology, real time disease response, samples should be analyzed quickly and results reported as soon as possible to public health officials. In such a scenario, samples are processed within hours of collection. However, sample storage remains essential. Samples may need to be stored for extended periods of time during transport or shipment from wastewater treatment plants to laboratories if the distance between them is far. In cases where a laboratory instrument malfunctions or results do not pass quality control metrics, samples might need to be rerun. Samples therefore need to be stored for at least as long as it takes to obtain laboratory results. Additionally, labs may want to create a biobank of samples; these samples can be used in the future to probe the presence of variants of concerns or other pathogens as needed. However, little is known about how sample storage affects the quantification of SARS-CoV-2 RNA in wastewater. If sample storage significantly changes the concentration of SARS-CoV-2 RNA relative to fresh, unstored samples, then measurements from stored samples may provide incorrect information on the incidence of COVID-19 in the sewersheds. The goal of this study is to provide data to help fill this knowledge gap.

Several studies have investigated how storage conditions affect quantification of SARS-CoV-2 RNA in wastewater to be used for wastewater based epidemiology, but most have focused on liquid influent $[8,11-14]$ and determined that storage and freeze thaws of the liquid influent can reduce measured concentrations of the viral RNA an order of magnitude or more. Only one study has examined persistence in wastewater solids: Hokajärvi et al. [12] examined degradation of SARS-CoV-2 RNA in solids pelleted from raw influent via centrifugation. The goal of this study is to assess the impact of different realistic storage conditions on the quantification of SARS-CoV-2 RNA and an endogenous viral control (pepper mild mottle virus, PMMoV) in wastewater settled solids (also referred to as primary settled solids or sludge). PMMoV is highly abundant in human stool and domestic wastewater globally $[15,16]$. The results of this study will inform optimal storage conditions for settled solids for use for wastewater-based epidemiology.

\section{Materials \& Methods}

\section{Schematic overview of the experimental approach.}

We collected settled solids from wastewater treatment plants and analyzed them immediately within 6 hours to measures SARS-CoV-2 RNA concentrations and PMMoV RNA concentrations. The samples were then stored under different conditions $\left(4^{\circ} \mathrm{C},-20^{\circ} \mathrm{C}\right.$, or $\left.-80^{\circ} \mathrm{C}\right)$ for different 
85

86

87

88

89

90

91

92

93

94

95

96

97

98

99

100

101

102

103

104

105

106

107

108

109

110

111

112

113

114

115

116

117

118

119

120

121

122

123

124

125

126

127

128

amounts of time and the SARS-CoV-2 RNA was measured again using the same analytical methods. The samples stored at $-80^{\circ} \mathrm{C}$ were first dewatered prior to storage. The measurements obtained immediately from the "fresh" sample (the "control") and measurements obtained from the same sample after storage (called "treatment") were then compared to assess how storage treatments affect the concentration of SARS-CoV-2 and PMMoV RNA. A schematic of the experimental approach is shown in Figure 1, and outlined in Table 1. Full details are provided below.

Sample collection. Eleven (11) 50-ml samples of settled solids were collected from the primary clarifiers at four unique wastewater treatment plants (Table 1) using sterile technique and clean containers. Samples were immediately stored on ice and transported to the lab where they were processed within 6 hours of sample pick up from the plants with high throughput methods [1719]. These un-stored samples are referred to as "controls". Thereafter, the samples were subjected to different storage treatments in the laboratory (Table 1). Raw samples were either stored at $4^{\circ} \mathrm{C}$ for $7,8,35,91$ or 122 days, or $-20^{\circ} \mathrm{C}$ for 2 or $3 \mathrm{~d}$. Four samples were stored as dewatered solids (described below) at $-80^{\circ} \mathrm{C}$ for 35,91 or 122 days. The lengths and temperatures of storage were chosen to represent the range of conditions under which we may need to store samples for our own wastewater surveillance project. After storage, refrigerated samples were immediately processed, and frozen samples were removed from freezers and defrosted at $4^{\circ} \mathrm{C}$ for 24 hours and then processed according to Topol et al. [17-19]. Stored samples are referred to as "treatments". In total, there were 16 samples subjected to a storage treatment.

Sample Preparation. The solids were dewatered by centrifugation at $24,000 \times \mathrm{g}$ for 30 minutes at $4{ }^{\circ} \mathrm{C}$ and aspirating and discarding the supernatant. A $0.5-1 \mathrm{~g}$ aliquot of the dewatered solids was dried at $110^{\circ} \mathrm{C}$ for $19-24$ hrs to determine its dry weight. Bovine coronavirus (BCoV) was used as a positive recovery control. Each day, attenuated bovine coronavirus vaccine (PBS Animal Health, Calf-Guard Cattle Vaccine) was spiked into DNA/RNA shield solution (Zymo Research, Irvine, CA, Cat \# R1100) at a concentration of $1.5 \mu \mathrm{L} / \mathrm{mL}$. Dewatered solids were resuspended in the BCoV-spiked DNA/RNA shield to a concentration of $75 \mathrm{mg} / \mathrm{mL}$. This concentration of solids was chosen as previous work titrated solutions with varying concentrations of solids to identify a concentration at which inhibition of the SARS-CoV-2 assays was minimized. Five to 10 5/32" Stainless Steel Grinding Balls (OPS Diagnostics, Lebanon, NJ, GBSS 156-5000-01) were added to each sample which was subsequently homogenized by shaking with a Geno/Grinder 2010 (Spex SamplePrep, Metuchen, NJ). Samples were then briefly centrifuged to remove air bubbles introduced during the homogenization process, and then vortexed to re-mix the sample.

RNA Extraction. RNA was extracted from 10 replicate aliquots per sample. For each replicate, RNA was extracted from $300 \mu$ l of homogenized sample using the Chemagic ${ }^{\text {TM }}$ Viral DNA/RNA 300 Kit H96 (Perkin Elmer, Akron, OH, Cat \# CMG-1033 S T) for the Chemagic 360 (Perkin Elmer, Akron, OH) followed by PCR Inhibitor Removal with the Zymo OneStep-96 PCR Inhibitor Removal Kit (Cat \# D6030). Extraction negative controls (water) and extraction positive controls (500 copies of SARS-CoV-2 genomic RNA (ATCC ${ }^{8}$ VR-1986D ${ }^{\mathrm{TM}}$ ) ) in the BCoV-spiked

Peerj reviewing PDF | (2021:04:60686:2:0:NEW 15 Jul 2021) 
129 DNA/RNA shield solution described above) were extracted using the same protocol as the

130

131

132

133

134

135

136

137

138

139

140

141

142

143

144

145

146

147

148

149

150

151

152

153

154

155

156

157

158

159

160

161

162

163

164

165

166

167

168

169

170

171

172 homogenized samples.

Digital PCR. RNA extracts were used as template in digital droplet RT-PCR assays for SARSCoV-2 N, S, and ORF1a RNA gene targets in a triplex assay, and BCoV and PMMoV in a duplex assay (see Table 2 for primer and probe sequences, purchased from Integrated DNA Technologies). Undiluted extract was used for the SARS-CoV-2 assay template and a 1:100 dilution of the extract was used for the BCoV / PMMoV assay template. Digital RT-PCR was performed on $20 \mu \mathrm{l}$ samples from a $22 \mu \mathrm{l}$ reaction volume, prepared using $5.5 \mu \mathrm{l}$ template, mixed with $5.5 \mu \mathrm{l}$ of One-Step RT-ddPCR Advanced Kit for Probes (Bio-Rad, Hercules, CA Cat \# 1863021), $2.2 \mu \mathrm{l}$ Reverse Transcriptase, $1.1 \mu \mathrm{l}$ DTT and primers and probes at a final concentration of $900 \mathrm{nM}$ and $250 \mathrm{nM}$ respectively. Droplets were generated using the AutoDG Automated Droplet Generator (Bio-Rad). PCR was performed using Mastercycler Pro with the following protocol: reverse transcription at $50^{\circ} \mathrm{C}$ for 60 minutes, enzyme activation at $95^{\circ} \mathrm{C}$ for 5 minutes, 40 cycles of denaturation at $95^{\circ} \mathrm{C}$ for 30 seconds and annealing and extension at either $59^{\circ} \mathrm{C}$ (for SARS-CoV-2 assay) or $56^{\circ} \mathrm{C}$ (for PMMoV/BCoV duplex assay) for 30 seconds, enzyme deactivation at $98^{\circ} \mathrm{C}$ for 10 minutes then an indefinite hold at $4^{\circ} \mathrm{C}$. The ramp rate for temperature changes were set to $2^{\circ} \mathrm{C} /$ second and the final hold at $4^{\circ} \mathrm{C}$ was performed for a minimum of 30 minutes to allow the droplets to stabilize. Droplets were analyzed using the QX200 Droplet Reader (Bio-Rad). All liquid transfers were performed using the Agilent Bravo (Agilent Technologies, Palo Alto, CA).

Each sample was run in 10 replicate wells, extraction negative controls were run in 7 wells, and extraction positive controls in 1 well. In addition, PCR positive controls for SARS-CoV-2 RNA, $\mathrm{BCoV}$, and PMMoV were run in 1 well, and NTC were run in 7 wells. Positive controls consisted of BCoV and PMMoV gene block controls (purchased from Integrated DNA Technologies) and gRNA of SARS-CoV-2 (ATCC $\circledast$ VR-1986D ${ }^{\mathrm{TM}}$ ). Results from replicate wells were merged for analysis. Thresholding was done using QuantaSoft ${ }^{\mathrm{TM}}$ Analysis Pro Software (Bio-Rad, version 1.0.596). Additional details are provided in supporting material per the dMIQE guidelines [20].

Data analysis. Concentrations of RNA targets were converted to concentrations per dry weight of solids in units of copies/g dry weight. The total error is reported as $68 \%$ confidence intervals and includes the errors associated with the poisson distribution and the variability among the 10 replicates. The recovery of $\mathrm{BCoV}$ was determined by normalizing the concentration of $\mathrm{BCoV}$ by the expected concentration given the value measured in the spiked DNA/RNA shield. If the $\mathrm{BCoV}$ recovery was less than $10 \%$, then the sample was rerun.

PMMoV, N, S, ORF1a, as well as N/PMMoV, S/PMMoV, and ORF1a/PMMoV were compared for each sample control and treatment, 1 by 1 , by examining the measurement and the $68 \%$ error associated with the measurement. The error associated with the quotients was estimated by propagating errors on the numerator and denominator, as described by Graham et al. [2]. In brief, the relative error of the quotient is approximated by the square root of the sum of the relative errors of the numerator and denominator squared. If the measurement of the treatment 
173 condition fell within the error range of the control condition, then the measurement was deemed

174 "not different". This approach is equivalent to a t-test where the null hypothesis $(\mathrm{Ho})$ is the value

175 of the treatment is the same as the control and the alternate hypothesis $\mathrm{(Ha})$ is that the values

176 are different. In this study, we are particularly concerned about type 2 errors (failing to reject Ho

177 when it is false) as we are concerned with whether storage renders different measurements. As

178 such, in order to increase the power of the analysis, we chose to make comparisons using the

$17968 \%$ confidence intervals. With the 10 replicates, this gives $\sim 90 \%$ power of avoiding a type 2

180 error assuming an effect size equal to the standard deviation. Note that if we had used $95 \%$

181 confidence intervals in our analysis rather than $68 \%$ confidence intervals, the likelihood of not

182 detecting a difference in the treatments and controls would be higher as $95 \%$ confidence

183 intervals are approximately two times larger than $68 \%$ confidence intervals.

184

185 For measurements deemed "different", the percent difference (\% diff) was calculated as \% diff

$186=100 \times$ (control-treatment)/control where control and treatment are the associated

187 measurements. A positive \% diff indicates that the treatment result is smaller than the control,

188 whereas a negative percent indicates the treatment had higher concentrations than the control.

189 Errors for \% diff were propagated from the measurements as standard deviations.

190

191

192

193

194

195

196

197

198

199

200

201

202

203

204

205

206

207

208

209

210

211

212

213

214

215

\section{Results}

Quality control. All positive extraction and PCR controls were positive, and all negative extraction controls and negative PCR controls were negative indicating no cross contamination between samples. Recovery of spiked BCoV was above $10 \%$ for all samples so no samples were rerun owing to unacceptable recovery. SARS-CoV-2 RNA and PMMoV targets were detected in all samples. Data from the experiments is available through Stanford Digital Repository [21].

Short-term Storage at $4^{\circ} \mathrm{C}$. Two experiments were carried out to investigate the effects of storage on 8 samples of raw settled solids samples at $4^{\circ} \mathrm{C}$ (Table 1). First, all samples were processed within 6 hours of collection and the resultant measurements were treated as those of the control condition. Then, in one experiment, 4 samples were stored for $7-8$ days at $4{ }^{\circ} \mathrm{C}$ prior to being processed a second time; and in the other, 4 samples were stored between 35 days and 122 days prior to being processed a second time. The stored conditions are referred to as treatments.

SARS-CoV-2 RNA measurements made after $7-8 \mathrm{~d}$ of storage at $4^{\circ} \mathrm{C}$ were not different from the control condition for 3 of the 4 samples; PMMoV was not different between treatment and control for all 4 of the samples. When SARS-CoV-2 RNA gene concentrations were normalized by $\mathrm{PMMoV}$ gene concentrations, the ratios were not different between treatment and control in any of the 4 samples (Figure 2). For the sample that had lower SARS-CoV-2 RNA gene concentrations in the treatment compared to the control, the concentrations of the $\mathrm{N}, \mathrm{S}$, and ORF1 genes differed by $60 \%, 80 \%$, and $73 \%$ respectively (Table 3 ). 
216 Long-term Storage at $4^{\circ} \mathrm{C}$. Longer storage at $4^{\circ} \mathrm{C}$ (between 35 and 122 days) resulted in

217 significantly lower measurements of SARS-CoV-2 RNA in 3 of the 4 tested samples, and lower

218 PMMoV RNA concentrations in 2 of 4 samples. Normalizing SARS-CoV-2 RNA concentrations

219 by PMMoV concentrations "corrected" the differences observed in 1 sample, but not the other 2.

220 For those 2 samples, ratios were lower and different in the treatments compared to the controls

221 (Figure 2). The difference between the treatment and controls are shown in Table 3. The

222 average difference in the measurements, when they were different, was $44 \%$.

223

224

225

Storage at $-20^{\circ} \mathrm{C}$. Four samples were processed within 6 hours of collection to obtain control measurements. The same samples were also frozen at $-20^{\circ} \mathrm{C}$ for 2 or 3 days, and then defrosted and processed to obtain treatment measurement (Table 1).

227

228

SARS-CoV-2 RNA concentrations in treatments were different in 3 of the 4 samples compared to controls (lower in treatment versus control in 1 and higher in 2, average difference 89\%).

230

231 PMMoV concentrations were not different between treatments and controls. Normalizing SARSCoV-2 RNA concentrations by PMMoV RNA concentrations, "corrected" the differences in

232

233

234

235 SARS-CoV-2 RNA observed in 2 of the 3 samples (Figure 3); for the single sample where the ratio of SARS-CoV-2 RNA to PMMoV RNA concentrations was different, the treatment had $61 \%$ (average) lower ratio than the control. Differences between treatments and controls are summarized in Table 3.

236

237

Storage at $-80^{\circ} \mathrm{C}$. Four samples were processed within 6 hours of collection to obtain control measurements and also dewatered, frozen at $-80^{\circ} \mathrm{C}$ for between 35 and 122 days, and then defrosted and processed to obtain treatment measurements (Table 1).

239

240

241

SARS-CoV-2 and PMMoV RNA concentrations were statistically lower in the treatments

242

243 compared to the controls by $40 \%$ to $90 \%$ (Figure 3 and Table 3 ). Normalizing SARS-CoV-2 RNA concentrations by PMMoV concentrations "corrected" the differences for 2 of the 4 samples. For the other 2, the ratio of SARS-CoV-2 RNA to PMMoV RNA concentrations was

245

246

247 $49 \%$ (on average) lower in the treatment than the control.

248

Overview of combined results. Across the treatment/samples where we observed a change in

249 SARS-CoV-2 RNA concentrations relative to the control $(n=11$ of 16$)$, there was a reduction in measured SARS-CoV-2 RNA concentration in all but 2 sample treatments (mean percent

250 reduction of $63 \% \pm 14 \%$ standard deviation, $n=27$ : 9 treatment/samples $\times 3$ SARS-CoV-2 gene

251

252 measurements different per treatment/sample). In the 2 cases where we observed an increase in SARS-CoV-2 concentrations in the treatment compared to the control, that increase was $107 \% \pm 44 \%$ on average $(n=4,2$ sample /treatments $\times 2$ SARS-CoV-2 genes were different per sample/treatment). All measurements made in samples receiving a treatment were within an

255

256

257

258 order of magnitude of the measurement in the control.

259 
260

261

262

263

264

265

266

267

268

269

270

271

272

273

274

275

276

277

278

279

280

281

282

283

284

285

286

287

288

289

290

291

292

293

294

295

296

297

298

299

300

301

302

SARS-CoV-2 RNA concentrations in wastewater settled solids correlate to COVID-19 incidence in surrounding sewersheds [1-5]. As a result, SARS-CoV-2 RNA concentrations in wastewater settled solids are being used to inform the response to the COVID-19 pandemic. While immediate processing of samples after they are collected is ideal, it is necessary to store and archive samples in case samples need to be rerun due to failed quality control metrics, or if additional analyses are needed to investigate the presence of other viruses or viral variants, for example. There is limited data on how storage of wastewater samples affects the concentration of SARS-CoV-2 RNA in the samples, so we carried out experiments to help fill this knowledge gap. Our experiments suggest that storage of wastewater settled solids samples, either refrigerated or frozen, may change the concentrations of SARS-CoV-2 RNA measured in the samples, but changes are less than an order of magnitude even for samples stored over 100 days.

Several studies have examined the effect of sample storage on SARS-CoV-2 RNA quantification in wastewater influent which represents a different matrix than that examined herein. Influent consists primarily of liquid wastewater rather than solids. Hokajärvi et al. [12] examined the effect of storage on detection of SARS-CoV-2 RNA in liquid influent and found small differences resulting from storage at freezing temperatures and first order decay of the RNA in influent stored at $4^{\circ} \mathrm{C}$ with a $T_{90}$ (time until $1 \log _{10}$ reduction of concentration) of 36 to 52 days depending on the genomic target. Ahmed et al. [14] report similar results as Hokajärvi et al. for decay of the SARS-CoV-2 targets in influent during storage at $4^{\circ} \mathrm{C}$. Markt et al. [22] found minimal differences in SARS-CoV-2 RNA concentrations measured in influent stored for up to 7 days at $4^{\circ} \mathrm{C}$ compared to concentrations measured with no storage, but found more than an order of magnitude decrease in SARS-CoV-2 RNA concentrations in samples that were stored frozen and subject to a freeze thaw. Fernandez-Cassi et al. [23] report extensive reduction in SARS-CoV-2 RNA concentrations measured in liquid wastewater stored at $4^{\circ} \mathrm{C}$ and $-20^{\circ} \mathrm{C}(1-2$ orders of magnitude). Our results regarding wastewater solids stored at $4^{\circ} \mathrm{C}$ are similar to those presented in these influent studies, except for Fernandez-Cassi et al. [23]; overall we saw minimal reduction (less than an order of magnitude) even for samples stored over 100 days. However, the effect of freeze thaw on our measurements with solids is small compared to those reported by Markt et al. [22] and Fernandez-Cassi et al. [23] for infuent. We could identify only one published study on SARS-CoV-2 RNA decay in solids: Hokajärvi et al. [12] report minimal decay (between $0 \%$ and $20 \%$ ) of SARS-CoV-2 RNA solids pelleted rom raw influent by centrifugation during storage at $4^{\circ} \mathrm{C},-20^{\circ} \mathrm{C}$, and $-75^{\circ} \mathrm{C}$ for 84 days, within the range of results reported herein.

Researchers have used PMMoV RNA as an internal process control in their efforts to monitor SARS-CoV-2 RNA in wastewater $[1,24,25]$. Assuming endogenous PMMoV RNA is recovered in the sample processing and RNA extraction and purification process in the same manner as SARS-CoV-2 RNA, then normalizing SARS-CoV-2 RNA by PMMoV RNA provides a ratio that does not depend on recovery. Wolfe et al. [1] showed the ratio of SARS-CoV-2 RNA/PMMoV RNA in settled solids is associated with COVID-19 incidence rates empirically, and the relationship between the ratio and COVID-19 incidence rates also falls from a mass balance

Peerj reviewing PDF | (2021:04:60686:2:0:NEW 15 Jul 2021) 
303 model that relates wastewater solid concentrations to the number of people shedding SARS-

304 CoV-2 RNA in their stool.

305

306

307

308

309

310

311

312

313

314

315

316

317

318

319

320

321

322

323

324

325

326

327

328

329

330

331

332

333

334

335

336

337

338

339

340

341

342

343

344

345

346

In this study, we found that normalizing SARS-CoV-2 RNA by PMMoV RNA concentrations corrected for changes in concentration that may result during storage. In 7 of the 11 sample/treatments that showed differences between SARS-CoV-2 RNA concentrations and the control, SARS-CoV-2/PMMoV was not different between treatment and control. When there were differences, they were less than an order of magnitude. PMMoV RNA concentration was often affected by storage in a similar manner as SARS-CoV-2 RNA concentrations, thus highlighting an additional benefit of using the internal control to interpret concentrations of the SARS-CoV-2 RNA targets in wastewater-based epidemiology applications. The ability to effectively correct for the impact of storage on samples suggests that the primary concerns for sample storage of wastewater solids are related to times when SARS-CoV-2 concentrations are nearing the limit of detection, and during periods of low incidence immediate sample processing should be a higher priority.

Additional research should examine a time course of decay of SARS-CoV-2 RNA for a single solids sample stored for various lengths of time, and also investigate the effects of multiple freeze thaws on target quantification. Work with additional viral targets may also be useful to provide guidance on storage for wastewater-based epidemiology applications beyond COVID19 including using RNA from gastro-intestinal viruses like norovirus and rotavirus to infer incidence of diarrheal illnesses. Finally, our study was not powered to investigate whether storage affected viral quantification in wastewater solids from different wastewater treatment plants in different ways; we used samples from diverse plants to capture potential variations between properties of wastewater solids. Additional work should investigate if storage has differential effects on samples from different wastewater treatment plants. Importantly, studies on the effect of storage on quantification of wastewater based epidemiology targets in wastewater influent and solids should be carried out in the near term, before there is a pressing need to use the measurements for disease outbreak response.

\section{Conclusions}

Wastewater based epidemiology is not a new field. It has previously been used to surveil populations for infectious diseases including polio [27], hepatitis [28], and salmonellosis [29]. Its wide-spread use globally during the COVID-19 pandemic to infer trends in COVID-19 incidence, however, is unprecedented. As such, new research is needed to continue to fill research gaps and develop models that link wastewater concentrations of pathogens to disease incidence rates.

One of those research gaps concerns storage of wastewater samples, and how storage affects measured concentrations of wastewater based epidemiology targets - in this case SARS-CoV-2 RNA. Storage of wastewater solids for use in wastewater-based epidemiology applications is essential. Here we examined how storage at $4^{\circ} \mathrm{C}$ for short (7-8 d) and long durations (35-122 d),

PeerJ reviewing PDF | (2021:04:60686:2:0:NEW 15 Jul 2021) 
$347-20^{\circ} \mathrm{C}$ for short $(2-3 \mathrm{~d})$, and $-80^{\circ} \mathrm{C}$ for long durations (35-122 d) affects SARS-CoV-2 RNA 348 measurements in wastewater solids, and whether normalizing measurements by concentrations 349 of an internal process control corrects for the effects of storage.

350

We found storage at $4^{\circ} \mathrm{C}$ for short durations of 7-8 days had limited to no effect on measured concentrations, but other storage conditions and durations affected concentrations by reducing them by $61 \%$, on average, and in one case increasing them by up to $170 \%$. However, we found that the normalizing concentrations by the internal process control PMMoV helped to correct for the observed differences.

Degradation of wastewater based epidemiology targets during storage represents a challenge to application of the tool for public health responses to infectious disease outbreaks. Storage of samples is essential. Identifying matrices and storage conditions where there is limited degradation is essential. With this in mind, we recommend short duration storage at $4^{\circ} \mathrm{C}$, and normalizing concentrations of SARS-CoV-2 RNA by concentrations of PMMoV RNA in the sample for use in models that relate trends in wastewater to disease incidence. Even under the longer storage conditions including those that required a freeze/thaw, changes in concentrations observed with the solids were less than one order of magnitude and similar among samples subjected to the same treatment.

\section{Acknowledgements}

We acknowledge the wastewater treatment plant staff for providing the samples. This study was performed on the ancestral and unceded lands of the Muwekma Ohlone people. We pay our respects to them and their Elders, past and present, and are grateful for the opportunity to live and work here.

372

373

374 


\section{References}

377

378

379

380

381

382

383

384

385

386

387

388

389

390

391

392

393

394

395

396

397

398

399

400

401

402

403

404

405

406

407

408

409

410

411

412

413

414

415

416

417

418

419

420

421

422

423

424

1. Wolfe MK, Archana A, Catoe D, Coffman M, Dorevitch S, Graham K, et al. Scaling of SARS-CoV-2 RNA in settled solids from multiple wastewater treatment plants to compare relative incidence of laboratory-confirmed COVID-19 in their sewersheds. Environmental Science \& Technology Letters. 2021; In revision.

2. Graham KE, Loeb SK, Wolfe MK, Catoe D, Sinnott-Armstrong N, Kim S, et al. SARS-CoV2 RNA in Wastewater Settled Solids Is Associated with COVID-19 Cases in a Large Urban Sewershed. Environ Sci Technol. 2021;55: 488-498. doi:10.1021/acs.est.0c06191

3. Peccia J, Zulli A, Brackney DE, Grubaugh ND, Kaplan EH, Casanovas-Massana A, et al. SARS-CoV-2 RNA concentrations in primary municipal sewage sludge as a leading indicator of COVID-19 outbreak dynamics. Nature Biotechnology. 2020;38: 1164-1167.

4. D'Aoust PM, Mercier E, Montpetit D, Jia J-J, Alexandrov I, Neault N, et al. Quantitative analysis of SARS-CoV-2 RNA from wastewater solids in communities with low COVID-19 incidence and prevalence. Water Research. 2021;188: 116560. doi:10.1016/j.watres.2020.116560

5. Kitamura K, Sadamasu K, Muramatsu M, Yoshida H. Efficient detection of SARS-CoV-2 RNA in the solid fraction of wastewater. Science of The Total Environment. 2021;763: 144587. doi:10.1016/j.scitotenv.2020.144587

6. United States Center for Disease Control. National Wastewater Surveillance System (NWSS). 2020 [cited 24 Aug 2020]. Available: https://www.cdc.gov/coronavirus/2019ncov/cases-updates/wastewater-surveillance.html

7. Medema G, Heijnen L, Elsinga G, Italiaander R, Brouwer A. Presence of SARSCoronavirus-2 RNA in Sewage and Correlation with Reported COVID-19 Prevalence in the Early Stage of the Epidemic in The Netherlands. Environ Sci Technol Lett. 2020;7: 511516. doi:10.1021/acs.estlett.0c00357

8. Weidhaas J, Aanderud ZT, Roper DK, VanDerslice J, Gaddis EB, Ostermiller J, et al. Correlation of SARS-CoV-2 RNA in wastewater with COVID-19 disease burden in sewersheds. Science of The Total Environment. 2021;775: 145790. doi:10.1016/j.scitotenv.2021.145790

9. Li B, Di DYW, Saingam P, Jeon MK, Yan T. Fine-Scale Temporal Dynamics of SARS-CoV2 RNA Abundance in Wastewater during A COVID-19 Lockdown. Water Research. 2021;197: 117093. doi:10.1016/j.watres.2021.117093

10. AWWA. Standard Methods for the Examination of Water and Wastewater. 21st ed. Baltimore: American Public Health Association, American Water Works Association, Water Environment Federation; 2005.

11. Whitney ON, Kennedy LC, Fan VB, Hinkle A, Kantor R, Greenwald H, et al. Sewage, Salt, Silica, and SARS-CoV-2 (4S): An Economical Kit-Free Method for Direct Capture of SARSCoV-2 RNA from Wastewater. Environ Sci Technol. 2021;55: 4880-4888. doi:10.1021/acs.est.0c08129

12. Hokajärvi A-M, Rytkönen A, Tiwari A, Kauppinen A, Oikarinen S, Lehto K-M, et al. The detection and stability of the SARS-CoV-2 RNA biomarkers in wastewater influent in Helsinki, Finland. Science of The Total Environment. 2021;770: 145274. doi:10.1016/j.scitotenv.2021.145274

13. Bivins A, Greaves J, Fischer R, Yinda KC, Ahmed W, Kitajima M, et al. Persistence of SARS-CoV-2 in Water and Wastewater. Environ Sci Technol Lett. 2020;7: 937-942. doi:10.1021/acs.estlett.0c00730

14. Ahmed W, Bertsch PM, Bibby K, Haramoto E, Hewitt J, Huygens F, et al. Decay of SARSCoV-2 and surrogate murine hepatitis virus RNA in untreated wastewater to inform application in wastewater-based epidemiology. Environmental Research. 2020; 110092. 
425

426

427

428

429

430

431

432

433

434

435

436

437

438

439

440

441

442

443

444

445

446

447

448

449

450

451

452

453

454

455

456

457

458

459

460

461

462

463

464

465

466

467

468

469

470

471

472

473

474

475 doi:10.1016/j.envres.2020.110092

15. Colson P, Richet H, Desnues C, Balique F, Moal V, Grob J-J, et al. Pepper Mild Mottle Virus, a Plant Virus Associated with Specific Immune Responses, Fever, Abdominal Pains, and Pruritus in Humans. PLOS ONE. 2010;5: e10041. doi:10.1371/journal.pone.0010041

16. Rosario K, Symonds EM, Sinigalliano C, Stewart J, Breitbart M. Pepper mild mottle virus as an indicator of fecal pollution. Applied and Environmental Microbiology. 2009;75: 72617.

17. Topol A, Wolfe M, White B, Wigginton K, Boehm A. High Throughput pre-analytical processing of wastewater settled solids for SARS-CoV-2 RNA analyses. protocols.io. 2021. Available: dx.doi.org/10.17504/protocols.io.btyqnpvw

18. Topol A, Wolfe M, White B, Wigginton K, Boehm A. High Throughput SARS-COV-2, PMMOV, and BCoV quantification in settled solids using digital RT-PCR. protocols.io. 2021. Available: dx.doi.org/10.17504/protocols.io.btywnpxe

19. Topol A, Wolfe M, Wigginton K, White B, Boehm A. High Throughput RNA Extraction and PCR Inhibitor Removal of Settled Solids for Wastewater Surveillance of SARS-CoV-2 RNA. protocols.io. 2021. Available: dx.doi.org/10.17504/protocols.io.btyrnpv6

20. The dMIQE Group, Huggett JF. The Digital MIQE Guidelines Update: Minimum Information for Publication of Quantitative Digital PCR Experiments for 2020. Clinical Chemistry. 2020;66: 1012-1029. doi:10.1093/clinchem/hvaa125

21. Simpson A, Boehm AB. Effect of storage on concentrations of SARS-CoV-2 RNA in settled solids of wastewater treatment plants. In: Stanford Digital Repository [Internet]. 2021. Available: purl.stanford.edu/yn042kx5009

22. Markt R, Mayr M, Peer E, Wagner AO, Lackner N, Insam H. Detection and stability of SARS-CoV-2 fragments in wastewater: Impact of storage temperature. medRxiv. 2021; 2021.02.22.21250768. doi:10.1101/2021.02.22.21250768

23. Fernandez-Cassi X, Scheidegger A, Bänziger C, Cariti F, Corzon AT, Ganesanandamoorthy P, Lemaitre, JC, Ort C, Julian TR, Kohn T. Wastewater monitoring outperforms case numbers as a tool to track COVID-19 incidence dynamics when test positivity rates are high. Water Research. 2021; 117252. doi:10.1016/j.watres.2021.117252

24. Wu F, Zhang J, Xiao A, Gu X, Lee WL, Armas F, Kauffman K, Hanage W, Matus M, Ghaeli N, Endo N, Duvallet C, Poyet M, Moniz K, Washburne A, Erickson T, Chai P, Thompson J, and Alm, EJ. SARS-CoV-2 Titers in Wastewater Are Higher than Expected from Clinically Confirmed Cases. mSystems. 2020;5: e00614-20. doi:10.1128/mSystems.00614-20

25. Feng S, Roguet A, McClary-Gutierrez JS, Newton RJ, Kloczko N, Meiman JG, McLellan, S. Evaluation of sampling frequency and normalization of SARS-CoV-2 wastewater concentrations for capturing COVID-19 burdens in the community. medRxiv. 2021; 2021.02.17.21251867. doi:10.1101/2021.02.17.21251867

26. Huisman JS, Scire J, Caduff L, Fernandez-Cassi X, Ganesanandamoorthy P, Kull A, Andreas Scheidegger, Elyse Stachler, Alexandria B. Boehm, Bridgette Hughes, Alisha Knudson, Aaron Topol, Krista R. Wigginton, Marlene K. Wolfe, Tamar Kohn, Christoph Ort, Tanja Stadler, Timothy R. Julian. Wastewater-based estimation of the effective reproductive number of SARS-CoV-2. medRxiv. 2021; 2021.04.29.21255961. doi:10.1101/2021.04.29.21255961

27. Brouwer, A. F.; Eisenberg, J. N. S.; Pomeroy, C. D.; Shulman, L. M.; Hindiyeh, M.; Manor, Y.; Grotto, I.; Koopman, J. S.; Eisenberg, M. C. Epidemiology of the Silent Polio Outbreak in Rahat, Israel, Based on Modeling of Environmental Surveillance Data. Proc Natl Acad Sci USA 2018, 115 (45), E10625. https://doi.org/10.1073/pnas.1808798115.

28. McCall, C.; Wu, H.; Miyani, B.; Xagoraraki, I. Identification of Multiple Potential Viral Diseases in a Large Urban Center Using Wastewater Surveillance. Water Research 2020, 184, 116160. https://doi.org/10.1016/j.watres.2020.116160. 
476 29. Diemert, S.; Yan, T. Clinically Unreported Salmonellosis Outbreak Detected via

477

478

479 Comparative Genomic Analysis of Municipal Wastewater <em>Salmonella</Em> Isolates. Appl. Environ. Microbiol. 2019, 85 (10), e00139-19.

https://doi.org/10.1128/AEM.00139-19.

480

481

482 


\section{Figure 1}

Figure 1. Schematic of experiment.

We collected settled solids from wastewater treatment plants and analyzed them immediately within 6 hours to measures SARS-CoV-2 RNA concentrations and PMMoV RNA concentrations. The samples were then stored under different conditions $\left(4^{\circ} \mathrm{C},-20^{\circ} \mathrm{C}\right.$, or $-80^{\circ} \mathrm{C}$ ) for different amounts of time and the SARS-CoV-2 RNA was measured again using the same analytical methods. The samples stored at $-80^{\circ} \mathrm{C}$ were first dewatered prior to storage. Created with BioRender.com.
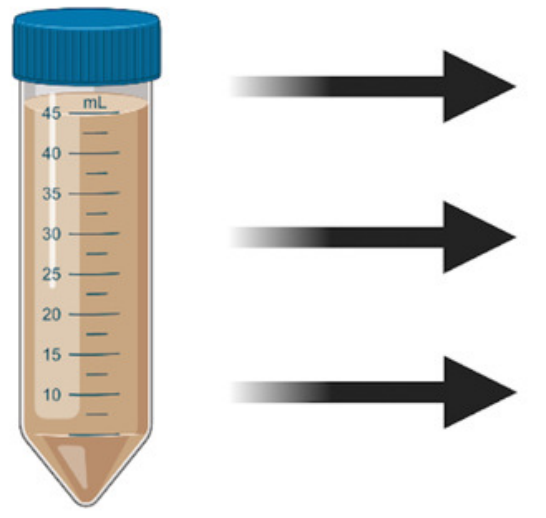

stored $7,8,35,91$, or 122 days at $4^{\circ} \mathrm{C}$ stored 2 or 3 days at $-20^{\circ} \mathrm{C}$

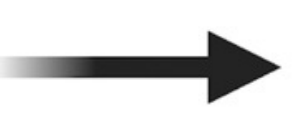

settled solids
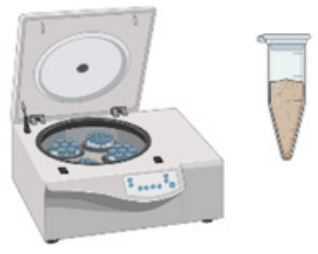

dewatered solids stored 53,91 , or 122 days at $-80^{\circ} \mathrm{C}$ 


\section{Figure 2}

Figure 2. Measurements in $4^{\circ} \mathrm{C}$ treatments and controls.

Concentrations of SARS-CoV-2 RNA targets (N, S, ORFla, left column) and PMMoV RNA (middle column), as well as their ratios (right column) as measured in settled solids in controls (darker bars) and treatments (lighter bars) and total errors as reported by the digital PCR instrument, or in the case of the ratios, the errors were propagated. Units are copies per gram dry weight $(\mathrm{cp} / \mathrm{g})$ for SARS-CoV-2 and PMMoV RNA targets, and there are no units for the ratio. Asterisks denote measurements or calculated ratios for which the errors on the treatments and controls do not overlap and indicate the measurements were different. Top row shows experiments where solids were stored at $4^{\circ} \mathrm{C}$ for 7-8 days while the bottom row shows experiments where solids were stored at $4^{\circ} \mathrm{C}$ for 35-122 days (see Table 1). The sample names on the $y$-axes consist of a letter indicating the plant location and a random number. The scales are different between plots to properly allow the plotting of the values which vary between samples. 
Stored at $4^{\circ} \mathrm{C}$ for $7-8$ days
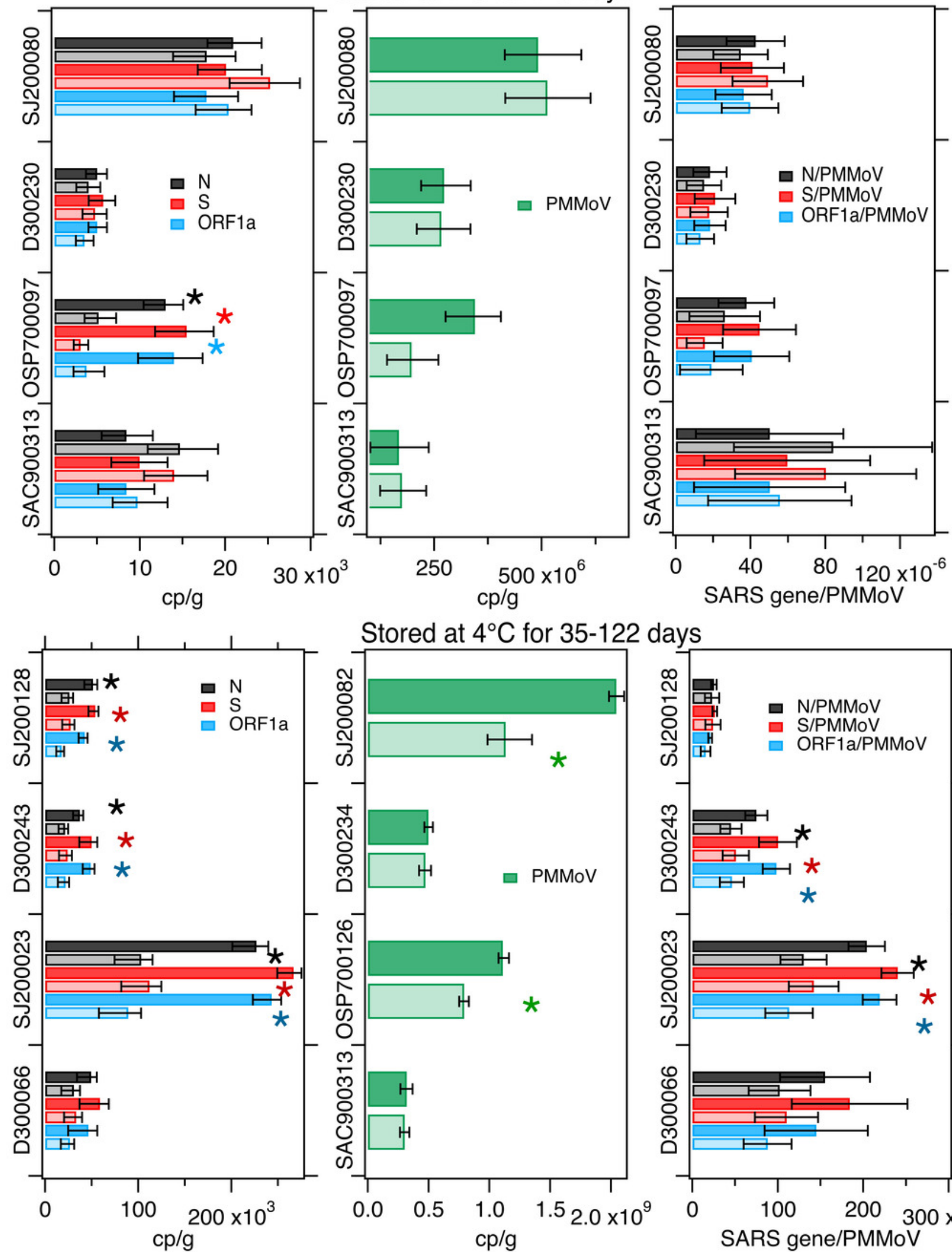

Stored at $4^{\circ} \mathrm{C}$ for $35-122$ days

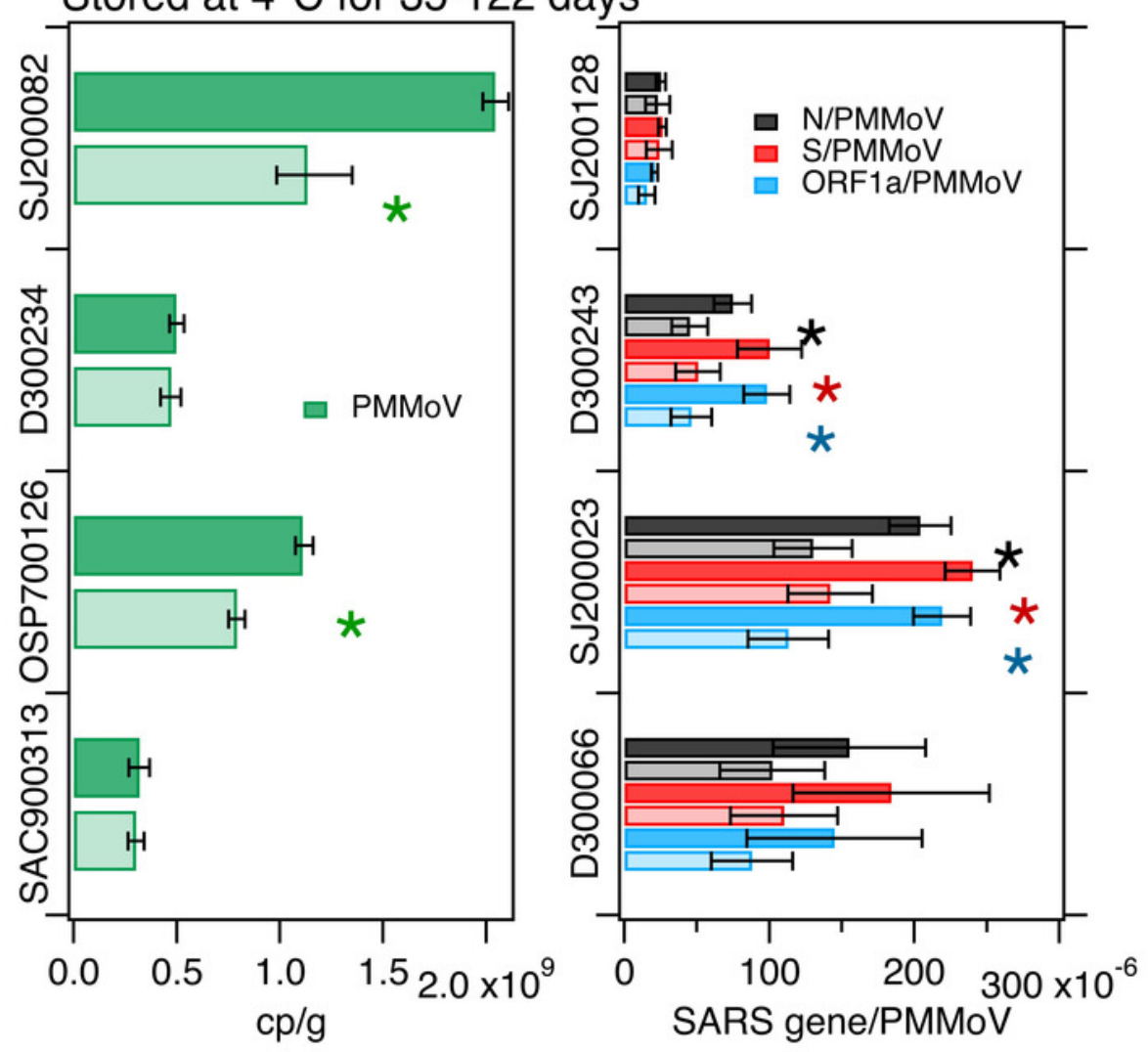




\section{Figure 3}

Figure 3. Comparison on measurements in freeze/thaw treatments and controls.

Concentrations of SARS-CoV-2 RNA targets (N, S, ORFla, left column) and PMMoV RNA (middle column), as well as their ratios (right column) as measured in settled solids in controls (darker bars) and treatments (lighter bars) and total errors as reported by the digital PCR instrument, or in the case of the ratios, the errors were propagated. Units are copies per gram dry weight $(\mathrm{cp} / \mathrm{g})$ for SARS-CoV-2 and PMMoV RNA targets, and there are no units for the ratio. Asterisks denote measurements or calculated ratios for which the errors on the treatments and controls do not overlap and indicate the measurements were different. Top row shows experiments where solids were stored at $-20^{\circ} \mathrm{C}$ for $2-3$ days while the bottom row shows experiments where dewatered solids were stored at $-80^{\circ} \mathrm{C}$ for $35-122$ days (see Table 1). 
Storage at $-20^{\circ} \mathrm{C}$ for $2-3$ days
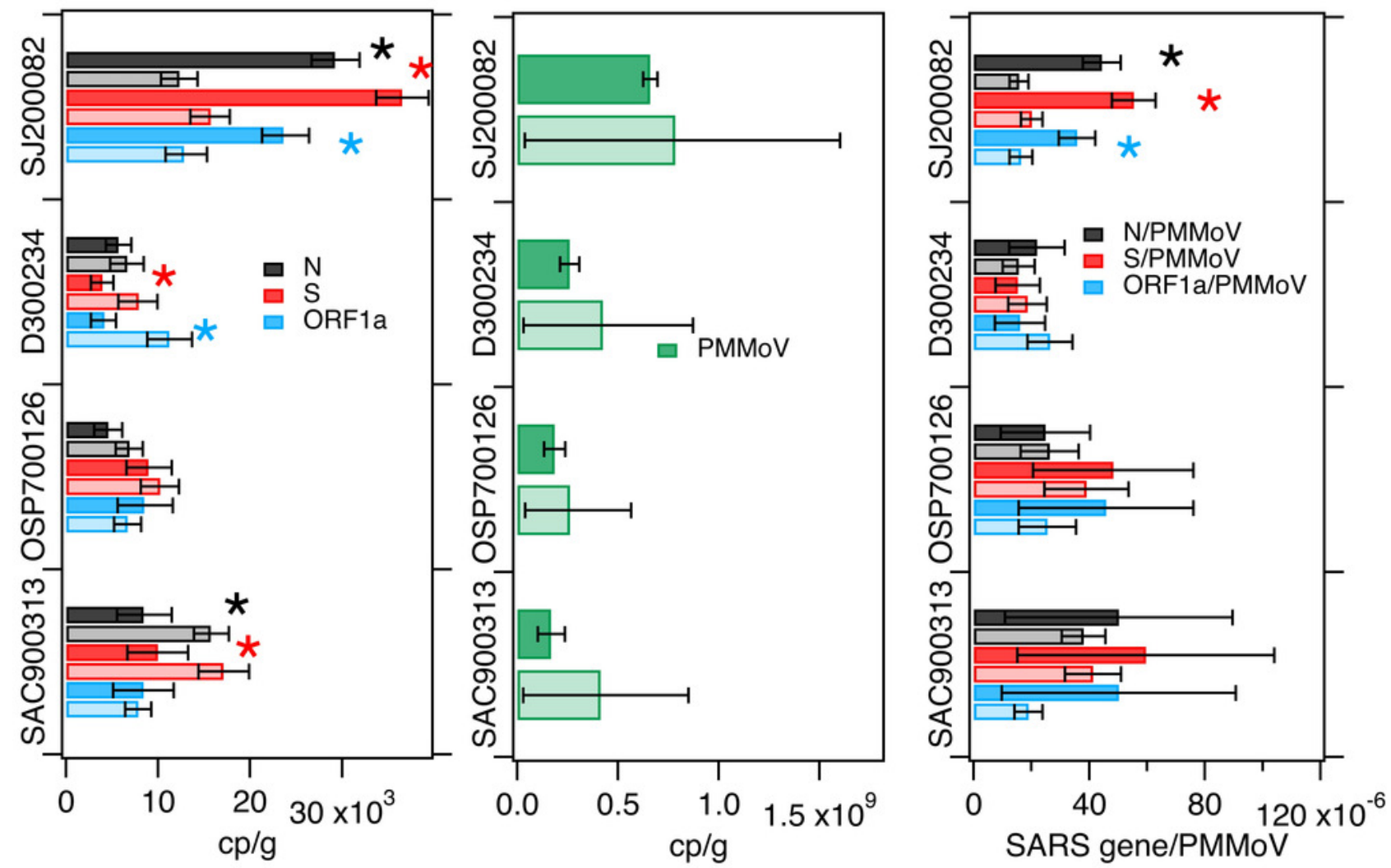

Storage at $-80^{\circ} \mathrm{C}$ for 35 to 122 days
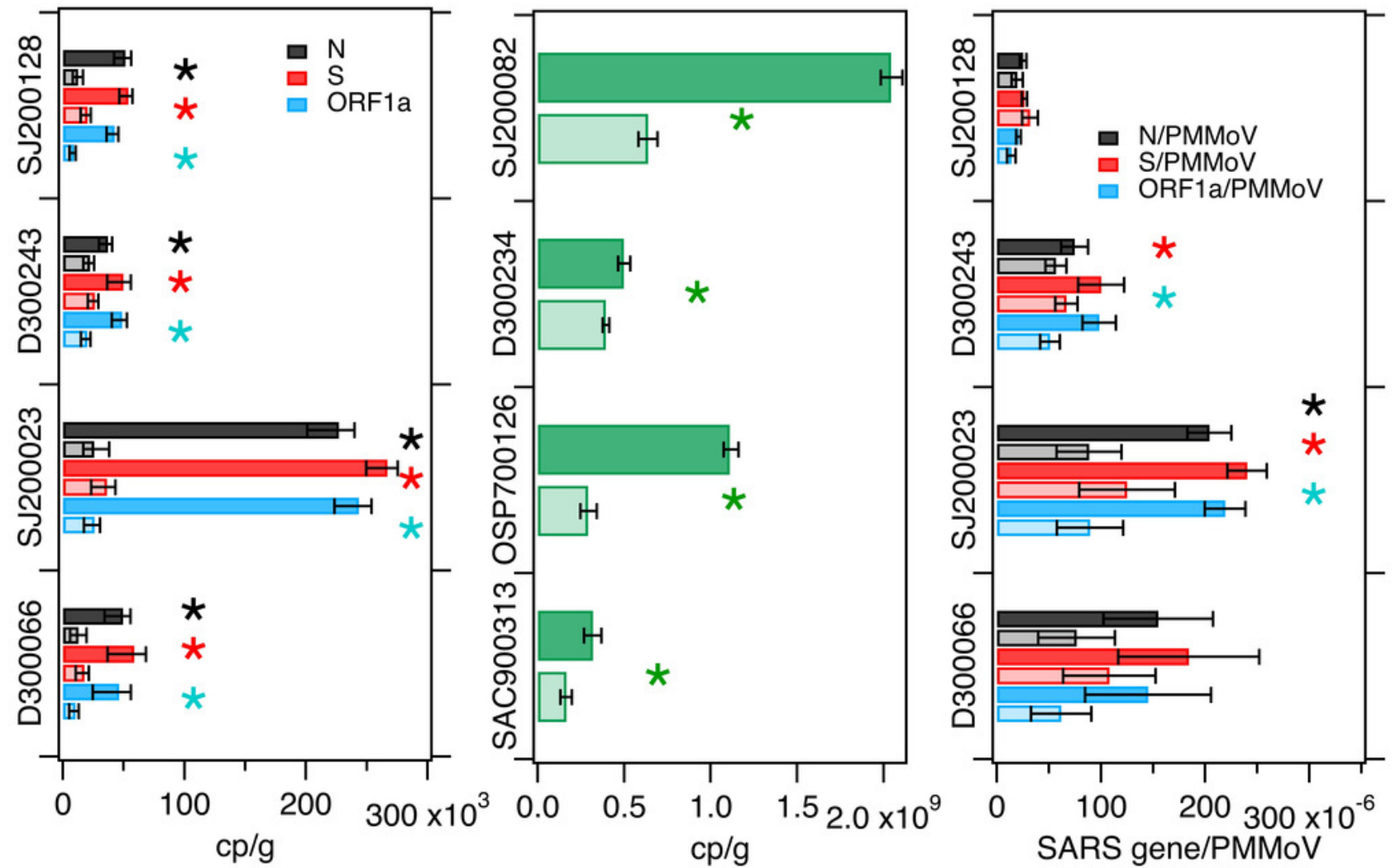


\section{Table $\mathbf{1}$ (on next page)}

Table 1. Samples used in this study.

Samples used in this study as well as the wastewater plant they were collected from (all located in California) and the date of sample collection, and the storage temperature and duration for the treatment applied to it. In order to protect the privacy of the plants and the inhabitants of their sewersheds, the precise locations are not provided herein. 


\begin{tabular}{|l|l|l|l|l|}
\hline Sample ID & Plant & Date & $\begin{array}{l}\text { Storage } \\
\text { condition(s) }\end{array}$ & $\begin{array}{l}\text { duration(s) of } \\
\text { storage }\end{array}$ \\
\hline SJ200080 & SJ & $2 / 28 / 21$ & $4^{\circ} \mathrm{C}$ & $8 \mathrm{~d}$ \\
\hline D300230 & D & $3 / 1 / 21$ & $4^{\circ} \mathrm{C}$ & $7 \mathrm{~d}$ \\
\hline OSP700097 & Ocean & $3 / 1 / 21$ & $4^{\circ} \mathrm{C}$ & $7 \mathrm{~d}$ \\
\hline SJ200082 & SJ & $2 / 23 / 21$ & $-20^{\circ} \mathrm{C}$ & $3 \mathrm{~d}$ \\
\hline D300234 & D & $2 / 24 / 21$ & $-20^{\circ} \mathrm{C}$ & $2 \mathrm{~d}$ \\
\hline OSP700126 & Ocean & $2 / 24 / 21$ & $-20^{\circ} \mathrm{C}$ & $2 \mathrm{~d}$ \\
\hline SAC900313 & SAC & $3 / 1 / 21$ & $4^{\circ} \mathrm{C} /-20^{\circ} \mathrm{C}$ & $7 \mathrm{~d} / 2 \mathrm{~d} *$ \\
\hline SJ200128 & SJ & $2 / 25 / 21$ & $4^{\circ} \mathrm{C} /-80^{\circ} \mathrm{C}$ & $35 \mathrm{~d}$ \\
\hline SJ20023 & SJ & $11 / 30 / 20$ & $4^{\circ} \mathrm{C} /-80^{\circ} \mathrm{C}$ & $122 \mathrm{~d}$ \\
\hline D300243 & D & $2 / 25 / 21$ & $4^{\circ} \mathrm{C} /-80^{\circ} \mathrm{C}$ & $35 \mathrm{~d}$ \\
\hline D300066 & D & $12 / 31 / 20$ & $4^{\circ} \mathrm{C} /-80^{\circ} \mathrm{C}$ & $91 \mathrm{~d}$ \\
\hline
\end{tabular}

$1{ }^{*}$ The sample stored at $-20^{\circ} \mathrm{C}$ was stored for $2 \mathrm{~d}$ and the sample stored at $4^{\circ} \mathrm{C}$ was stored for 7 2 d. 


\section{Table 2 (on next page)}

Table 2. The molecular targets used in this study as well as the primer and probe sequences.

The molecular targets used in this study as well as the primer and probe sequences. The N, $\mathrm{S}$, and ORFla genes are located within SARS-CoV-2 genome. The BCoV target is for bovine coronavirus, a process control spiked into the sample during processing. PMMoV is for the internal endogenous control which is naturally present in high concentrations in the samples. Additional details of these assays can be found in Huisman et al. [26] . 


\begin{tabular}{|c|c|c|}
\hline Target & Primer/Probe & Sequence \\
\hline \multirow[t]{3}{*}{ N Gene } & Forward & CATTACGTTTGGTGGACCCT \\
\hline & Reverse & CCTTGCCATGTTGAGTGAGA \\
\hline & Probe & CGCGATCAAAACAACGTCGG (5' FAM/ZEN/3' IBFQ) \\
\hline \multirow[t]{3}{*}{ S Gene } & Forward & CAGACTAATTCTCCTCGGCG \\
\hline & Reverse & TGCACCAAGTGACATAGTGT \\
\hline & Probe & AGCTAGTCAATCCATCATTGCCT (5' HEX/ZEN/3' IBFQ) \\
\hline \multirow[t]{3}{*}{ ORF1a } & Forward & CAGAACTGGAACCACCTTGT \\
\hline & Reverse & TACAGTTGAATTGGCAGGCA \\
\hline & Probe & TGCCACAGTACGTCTACAAGC (5' FAM or HEX/ZEN/3' IBFQ) \\
\hline \multirow[t]{3}{*}{$\mathrm{BCoV}$} & Forward & CTGGAAGTTGGTGGAGTT \\
\hline & Reverse & ATTATCGGCCTAACATACATC \\
\hline & Probe & CCTTCATATCTATACACATCAAGTTGTT ( $5^{\prime}$ FAM/ZEN/3' IBFQ) \\
\hline \multirow[t]{3}{*}{ PMMoV } & Forward & GAGTGGTTTGACCTTAACGTTTGA \\
\hline & Reverse & TTGTCGGTTGCAATGCAAGT \\
\hline & Probe & CCTACCGAAGCAAATG (5' HEX/ZEN/3’ IBFQ) \\
\hline
\end{tabular}




\section{Table 3 (on next page)}

Table 3. Results for comparisons between experimental treatments and controls.

The percent difference (\% diff) in SARS-CoV-2 RNA measured in treatments versus their control is shown then the difference was significantly different. " $N$ " indicates that measurements or ratios were not different. The value after the \pm is the standard deviation propagated from the measurements used to make the calculation. A positive percent difference indicates the treatment was lower than the control, a negative percent difference indicates the treatment was higher in the control. See methods for more details on the calculations. 


\begin{tabular}{|c|c|c|c|c|c|c|c|c|}
\hline Sample & Treatment & $\% \operatorname{diff} \mathrm{N}$ & $\%$ diff S & $\begin{array}{l}\% \text { diff } \\
\text { ORF1a }\end{array}$ & $\begin{array}{l}\% \text { diff } \\
\text { PMMoV }\end{array}$ & $\begin{array}{l}\% \text { diff } \\
\text { N/PMMoV }\end{array}$ & $\begin{array}{l}\% \text { diff } \\
\text { S/PMMoV }\end{array}$ & $\begin{array}{l}\% \text { diff } \\
\text { ORF1a/PMMoV }\end{array}$ \\
\hline SJ200080 & $4^{\circ} \mathrm{C} / 8 \mathrm{~d}$ & $\mathrm{~N}$ & $\mathrm{~N}$ & $\mathrm{~N}$ & $\mathrm{~N}$ & $\mathrm{~N}$ & $\mathrm{~N}$ & $\mathrm{~N}$ \\
\hline D300230 & $4^{\circ} \mathrm{C} / 7 \mathrm{~d}$ & $\mathrm{~N}$ & $\mathrm{~N}$ & $\mathrm{~N}$ & $\mathrm{~N}$ & $\mathrm{~N}$ & $\mathrm{~N}$ & $\mathrm{~N}$ \\
\hline SAC900313 & $4^{\circ} \mathrm{C} / 7 \mathrm{~d}$ & $\mathrm{~N}$ & $\mathrm{~N}$ & $\mathrm{~N}$ & $\mathrm{~N}$ & $\mathrm{~N}$ & $\mathrm{~N}$ & $\mathrm{~N}$ \\
\hline OSP700097 & $4^{\circ} \mathrm{C} / 7 \mathrm{~d}$ & $60 \pm 48$ & $80 \pm 49$ & $73 \pm 67$ & $\mathrm{~N}$ & $\mathrm{~N}$ & $\mathrm{~N}$ & $\mathrm{~N}$ \\
\hline SJ200128 & $4^{\circ} \mathrm{C} / 35 \mathrm{~d}$ & $49 \pm 22$ & $49 \pm 19$ & $59 \pm 19$ & $45 \pm 15$ & $\mathrm{~N}$ & $\mathrm{~N}$ & $\mathrm{~N}$ \\
\hline D300243 & $4^{\circ} \mathrm{C} / 35 \mathrm{~d}$ & $42 \pm 23$ & $52 \pm 31$ & $55 \pm 22$ & $\mathrm{~N}$ & $40 \pm 41$ & $50 \pm 48$ & $53 \pm 49$ \\
\hline SJ200023 & $4^{\circ} \mathrm{C} / 122 \mathrm{~d}$ & $55 \pm 16$ & $58 \pm 12$ & $63 \pm 14$ & $29 \pm 10$ & $36 \pm 27$ & $41 \pm 23$ & $48 \pm 26$ \\
\hline D300066 & $4^{\circ} \mathrm{C} / 91 \mathrm{~d}$ & $\mathrm{~N}$ & $\mathrm{~N}$ & $\mathrm{~N}$ & $\mathrm{~N}$ & $\mathrm{~N}$ & $\mathrm{~N}$ & $\mathrm{~N}$ \\
\hline SJ200082 & $-20^{\circ} \mathrm{C} / 3 \mathrm{~d}$ & $58 \pm 21$ & $57 \pm 18$ & $46 \pm 28$ & $\mathrm{~N}$ & $65 \pm 32$ & $64 \pm 29$ & $54 \pm 38$ \\
\hline D300234 & $-20^{\circ} \mathrm{C} / 2 \mathrm{~d}$ & $\mathrm{~N}$ & $-100 \pm 56$ & $-170 \pm 35$ & $\mathrm{~N}$ & $\mathrm{~N}$ & $\mathrm{~N}$ & $\mathrm{~N}$ \\
\hline SAC900313 & $-20^{\circ} \mathrm{C} / 2 \mathrm{~d}$ & $-86 \pm 28$ & $-71 \pm 38$ & $\mathrm{~N}$ & $\mathrm{~N}$ & $\mathrm{~N}$ & $\mathrm{~N}$ & $\mathrm{~N}$ \\
\hline OSP700126 & $-20^{\circ} \mathrm{C} / 2 \mathrm{~d}$ & $\mathrm{~N}$ & $\mathrm{~N}$ & $\mathrm{~N}$ & $\mathrm{~N}$ & $\mathrm{~N}$ & $\mathrm{~N}$ & $\mathrm{~N}$ \\
\hline SJ200128 & $-80^{\circ} \mathrm{C} / 35 \mathrm{~d}$ & $76 \pm 21$ & $62 \pm 17$ & $79 \pm 18$ & $79 \pm 18$ & $\mathrm{~N}$ & $\mathrm{~N}$ & $\mathrm{~N}$ \\
\hline D300243 & $-80^{\circ} \mathrm{C} / 35 \mathrm{~d}$ & $40 \pm 21$ & $47 \pm 27$ & $59 \pm 19$ & $21 \pm 13$ & $\mathrm{~N}$ & $33 \pm 40$ & $48 \pm 33$ \\
\hline SJ200023 & $-80^{\circ} \mathrm{C} / 122 \mathrm{~d}$ & $89 \pm 13$ & $86 \pm 9$ & $89 \pm 10$ & $74 \pm 13$ & $57 \pm 32$ & $48 \pm 31$ & $59 \pm 29$ \\
\hline D300066 & $-80^{\circ} \mathrm{C} / 91 \mathrm{~d}$ & $75 \pm 38$ & $70 \pm 42$ & $78 \pm 51$ & $49 \pm 34$ & $\mathrm{~N}$ & $\mathrm{~N}$ & $\mathrm{~N}$ \\
\hline
\end{tabular}

